\title{
THE EFFECT OF PROFITABILITY AND INVESTMENT OPPORTUNITY SET ON CASH DIVIDEND WITH LIQUIDITY AS MODERATE VARIABLES (Studied at Kompas 100 that listed on JSX in 2008-2012 period)
}

\author{
Farida Titik Kristanti (farida_titik@yahoo.com) \\ Fitrianingsih (fitrianingsih1209@gmail.com) \\ Telkom Business School, Telkom University
}

\begin{abstract}
Dividend policy is profits which will be distributed to shareholders as dividends and/or retained earnings that will be retained as financing for investments in the future. There are many factors that influenced dividen policy, such as, profitability, cash flow, price earning ratio, leverage, inventory turnover, etc. This study aimed to determine the influence of profitability and the investment opportunity set to the cash dividend policy with liquidity as a moderating variabel. The object of the research is emiten of Kompas 100 that listed on the Indonesian Stock Exchange in 2008-2012 period. The selection of the sample using Purposive sampling method that samples were obtained by 10 companies. Analytical methods used to test the hypothesis is Moderated Regression Analysis (MRA).Results of this study showed that the profitability and the investment opportunity set simultaneously significant effect on dividend policy with liquidity as a moderating variable. Regression coefficient indicates that $25.6 \%$ of the independent variables explain the dependent variable, the remaining $74.4 \%$ is explained by other variables. Partially profitability have no significant effect to the dividend policy with the positive direction, while investment opportunity set have significant influence to the cash dividen policy with a negative direction. The Liquidity able to moderate the relationship of profitability to the cash dividend policy with a negative direction, while the investment opportunit set can be moderated by liquidity to the dividend policy with a positive direction.
\end{abstract}

\section{Keyword : Dividend Policy, Liquidity, Profitability, and Set Investment Opportunities}

\section{PENDAHULUAN}

Indeks Kompas 100 diterbitkan di Bursa Efek Indonesia dengan tujuan utama untuk menyebarluaskan informasi pasar modal serta menggairahkan masyarakat untuk mengambil manfaat dari keberadaan BEI, baik untuk investasi maupun mencari pendanaan bagi perusahaan dalam mengembangkan perekonomian nasional. Saham-saham yang terpilih untuk dimasukkan dalam indeks Kompas 100 ini selain memiliki likuiditas yang tinggi, serta nilai kapitalisasi pasar yang besar, juga merupakan saham-saham yang memiliki fundamental dan kinerja yang baik. Kompas 100 telah menunjukkan kinerja yang cukup mengesankan meski baru diluncurkan (10 agustus 2007), data per 9 November 2007 atau tiga bulan setelah indeks Kompas 100 diluncurkan, mencatat kenaikan sebesar 26,4 persen bila dibandingkan dengan IHSG BEI yang hanya 20 persen. Kompas 100 memuat 100 saham blue chips yaitu saham yang memiliki kinerja keuangan yang sehat (www.kompas.com).

Kebijakan dividen merupakan suatu kebijakan dari manajemen perusahaan dalam penetapan laba yang tersedia untuk dibayarkan kepada para pemegang saham dalam bentuk dividen atau laba yang di tahan. Jika manajemen memutuskan untuk membayar dividen maka jumlah laba 
di tahan menjadi berkurang, sehingga sumber pendanaan internal juga akan berkurang. Jika manajemen memutuskan tidak membayar dividen, maka pendanaan dari sumber dana internal akan meningkat. Kemampuan menghimpun pendanaan internal akan semakin memperkuat posisi ekuitas pemilik dikarenakan semakin kecil ketergantungan perusahaan pada sumber pendanaan eksternal (Darminto 2008).

Pihak yang berkepentingan dalam keputusan kebijakan dividen adalah pemegang saham sebagai pemilik perusahaan yang selanjutnya disebut principal dan pihak manajemen sebagai pihak yang diberi kepercayaan pemegang saham untuk mengelola perusahaan yang selanjutnya disebut agent. Konflik kepentingan muncul dari hubungan antara principal dan agent. Para manajer sering kali tergoda untuk meningkatkan kesejahteraannya sendiri dan bukan memaksimumkan kemakmuran shareholder dalam menjalankan operasi perusahaan. Umumnya pihak manajemen menahan kas untuk melunasi hutang atau meningkatkan investasi yang dapat memberikan pengembalian berupa cash inflow bagi perusahaan. Di sisi lain, pemegang saham mengharapkan dividen kas dalam jumlah relatif besar karena ingin menikmati hasil investasi pada saham perusahaan (Suharli 2007).

Salah satu perusahaan yang mengalami konflik kepentingan adalah perusahaan Apple. Chief Executive Officer Apple Inc, Tim Cook mengatakan Apple sedang melanjutkan diskusi aktif mengenai apa yang akan dilakukan dengan 97,6 miliar dollar dalam kas dan investasi. Beberapa investor meminta Apple untuk mengembalikan dana tunai kepada investor dalam bentuk dividen tunai atau pengembalian kembali saham karena Apple sudah tidak membagikan dividen sejak tahun 1995. Pada saat itu sang pendiri Steve Jobs sebagai $C E O$ menolak untuk membagikan dividen tunai kepada para investor. Hal ini dikarenakan laba perusahaan yang ada digunakan untuk investasi kedalam pengenalan produk iPod, iPhone, dan iPad telah mengambalikan perusahaan sebagai mesin profit (Suryanto 2012). Hal ini berbeda dengan penelitian yang dilakukan oleh (Suharli 2007), perusahaan yang memiliki profitabilitas yang tinggi cenderung membagikan dividen lebih banyak kepada para pemegang saham untuk meningkatkan kemakmuran pemegang saham sehingga dapat meningkatkan nilai perusahaan.

Peristiwa yang terjadi pada perusahaan Apple berbeda dengan Perusahaan PT. Adaro Energy Tbk yang membagikan dividen tunai senilai $\mathrm{Rp} 970,77$ miliar atau 43,98\% dari total laba bersih perseroan per Desember 2010 yang nilainya mencapai Rp 2,2 triliun. Sekretaris Perusahaan Adaro, Devindra Ratzarwin mengatakan dividen ini merupakan yang terbesar terhitung sejak perseroan mencatatkan sahamnya di bursa. Sebagian dividen tersebut telah dibayarkan pada Desember 2010 sebagai dividen interm sebesar Rp 315,06 miliar. Sisanya sebesar Rp 655,71 miliar akan digunakan untuk pembayaran dividen final dan Rp 1,13 triliun sisa laba bersih dimasukkan sebagai laba di tahan (Adminkepri 2011). Hal ini berbeda dengan hasil penelitian yang dilakukan oleh (Suharli 2007), perusahaan yang memilih menggunakan laba yang tersedia sebagai laba di tahan cenderung membagikan dividen yang relatif kecil.

Dalam hubungannya dengan pendapatan dividen, para investor umumnya menginginkan pembagian dividen yang relatif stabil dan dalam bentuk tunai. Hal ini dapat meningkatkan kepercayaan investor terhadap perusahaan sehingga mengurangi ketidakpastian investor dalam menanamkan dananya kedalam perusahaan.

Ada beberapa faktor yang dapat mempengaruhi kebijakan dividen, yaitu: free cash flow, profitabilitas, likuiditas, dan leverage (Arilaha 2009); EPS, PER, CR, DER, NPM, ITO, ROI (Fahrurrozi 2007); sedangkan menurut Ahmad (2009), faktor yang mempengaruhi kebijakan 
dividen adalah profitabilitas dan set kesempatan investasi yang diperkuat oleh likuiditas. Hal ini juga didukung oleh penelitian Suharli (2007) yang menyatakan bahwa kebijakan dividen tunai dipengaruhi oleh profitabilitas dan set kesempatan investasi yang diperkuat oleh likuiditas perusahaan. Pihak menajemen akan membayarkan dividen untuk memberi sinyal mengenai keberhasilan perusahaan dalam menghasilkan profit (Wirjolukito et.al, 2003).

Profitabilitas mutlak diperlukan untuk perusahaan apabila hendak membayarkan dividen (Suharli, 2007). Menurut Arifin (2005), Rasio profitabilitas digunakan untuk mengukur seberapa besar kemampuan perusahaan memperoleh laba dalam hubungan dengan penjualan, aktiva, maupun laba dan modal sendiri. Ada dua (2) rasio yang digunakan untuk mengukur profitabilitas, yaitu: Return on Investment (ROI) yang merupakan tingkat pengembalian investasi atas investasi pada aktiva dan Return on Equity (ROE) yang merupakan tingkat pengembalian atas ekuitas pemilik perusahaan.(Suharli 2007). Penelitian ini menggunakan proksi ROI sebagai ukuran profitabilitas perusahaan. Pertimbangan utama menggunakan proksi $R O I$ karena hasil yang didapat lebih menggambarkan profitabilitas. Hasil penelitian yang dilakukan oleh Arilaha (2009) menyatakan bahwa profitabilitas berpengaruh positif terhadap kebijakan dividen tunai.

Investment Opportunity Set (IOS) diperkenalkan pertama kali oleh Myers pada tahun 1977 . IOS merupakan nilai perusahaan yang besarnya tergantung pada pengeluaran-pengeluaran yang ditetapkan manajemen di masa yang akan datang, yang pada saat ini merupakan pilihanpilihan investasi yang diharapkan akan menghasilkan return yang lebih besar. Perusahaan menyukai pembiayaan internal yaitu laba ditahan daripada pembiayaan eksternal untuk membiayai kesempatan investasinya karena lebih efisien. Perusahaan yang sedang mengalami pertumbuhan akan membutuhkan banyak dana sehingga kebijakan dividen akan terpengaruh. Semakin cepat tingkat pertumbuhan perusahaan makin besar dana yang dibutuhkan, makin besar kesempatan untuk memperoleh keuntungan, makin besar return earning dalam perusahaan yang berarti makin rendah dividen payout ratio. Proksi yang digunakan dalam penelitian ini untuk set kesempatan investasi adalah market to book value of assets (MBVA). Penelitian Wirjolukito et al. (2003); Sudaryanti (2009); Marpaung dan Hadianto (2009) yang mengukur pemanfaatan kesempatan investasi dengan peningkatan aktiva tetap bersih menemukan bahwa pengaruh variabel peluang investasi kepada kebijakan dividen bernilai positif. Hasil penelitian ini mengindikasikan bahwa perusahaan di Indonesia yang menjadi sampel di dalam penelitian tentang dividen cenderung menggunakan kebijakan dividen untuk memberikan sinyal atas arus kas di masa yang akan datang dan menggunakan arus kas tersebut untuk mendanai investasi yang menguntungkan di masa yang akan datang.

Dividen dibayar dengan kas sehingga kemampuan membayar dividen sangat ditentukan oleh posisi likuiditas perusahaan. Likuiditas perusahaan adalah salah satu fator penting dalam keputusan dividen, semakin besar posisi kas dan likuiditas menyeluruh dari perusahaan maka semakin besar pula kemampuan untuk membayar dividen. Likuiditas sebagai variabel moderator dalam penelitian ini diproksikan oleh current ratio $(C R)$. Likuiditas dapat diartikan sebagai kemampuan suatu perusahaan memenuhi kewajiban-kewajiban keuangannya dalam jangka pendek atau yang harus segera dibayar. Pemilihan likuiditas sebagai variabel penguat karena pada perusahaan yang memiliki profitabilitas tinggi ditambah likuiditas yang lebih baik, maka semakin besar jumlah dividen yang dibagikan sehingga dapat meningkatkan kepercayaan investor terhadap perusahaan dan mengurangi ketidakpastian investor dalam menanamkan dananya ke dalam perusahaan. 
Berdasarkan latar belakang tersebut, maka dapat diidentifikasikan permasalahan sebagai berikut:

1. Bagaimana pengaruh profitabilitas terhadap kebijakan dividen tunai?

2. Bagaimana pengaruh secara set kesempatan investasi terhadap kebijakan dividen tunai?

3. Bagaimana pengaruh profitabilitas terhadap kebijakan dividen tunai dengan likuiditas sebagai variabel penguat?

4. Bagaimana pengaruh set kesempatan investasi terhadap kebijakan dividen tunai dengan likuiditas sebagai variabel penguat?

Berdasarkan permasalah tersebut, maka dalam penelitian ini penulis bertujuan ingin menguji pengaruh profitabilitas dan set kesempatan investasi terhadap kebijakan jumlah dividen perusahaan pada Kompas 100 dengan likuiditas sebagai variabel penguat (variabel moderator). Profitabilitas diukur dengan return on investment (ROI), kesempatan investasi diproksikan oleh market to book value of assets (MBVA), kebijakan dividen tunai diproksikan dengan dividen payout ratio dan likuiditas sebagai variabel moderat diproksikan oleh current ratio di Bursa Efek Indonesia.

\section{LANDASAN TEORI DAN PENGEMBANGAN HIPOTESIS}

\section{Dividen}

Dividen adalah sumber aliran kas perusahaan yang memberikan informasi tentang kinerja perusahaan saat ini maupun yang akan datang. Dividen adalah pembagian kepada pemegang saham dari suatu perusahaan secara proporsional sesuai dengan jumlah lembar saham yang dipegang oleh masing-masing pemiliknya (Stice et al. 2005:902).

Menurut Warsono (2003:275), Indikator untuk mengukur kebijakan dividen yang secara luas digunakan ada dua macam, yaitu:

1. Hasil Dividen (Dividend Yield), yaitu suatu rasio yang menghubungkan dividen yang dibayar dengan harga saham biasa.

2. Rasio Pembayaran Dividen (Dividend Payout Ratio/DPR), yaitu merupakan rasio hasil perbandingan antara dividen dengan laba yang tersedia bagi para pemegang saham biasa.

Ada banyak factor yang mempengaruhi kebijakan dividen di perusahaan. Faktor-faktor dapat disebutkan antara lain adalah Dividen Stabil, Perjanjian Hutang, Pembatasan dari Saham Preferen, Tersedianya Kas, Pengendalian, Kebutuhan Dana untuk Investasi, Fluktuasi Laba (Atmaja 2008).

Ada banyak teori tentang kebijakan dividen. Dalam Atmaja (2008) disebutkan:

1. Irrelevance theory. Teori ini menyatakan bahwa kebijakan dividen tidak mempunyai pengaruh baik terhadap nilai perusahaan maupun terhadap biaya modalnya. Menurut teori yang diperkenalkan oleh Modligiani dan Miller ini, kebijakan dividen tidak mempengaruhi harga saham ataupun cost of capital perusahaan.

2. Bird-in-the-hand theory. Teori yang dikemukakan oleh Gordon bahwa pendapatan dividen ( $a$ bird in-the hand) mempunyai nilai yang lebih tinggi bagi investor daripada pendapatan modal (a bird in-the bush) karena dividen lebih pasti dari pendapatan modal.

3. Tax preference theory. Teori ini diajukan oleh Litzenberger dan Ramaswamy. Mereka menyatakan bahwa karena adanya pajak terhadap keuntungan dividen dan capital gain, para investor lebih menyukai capital gain karena dapat menunda pembayaran pajak. Oleh 
karena itu, investor mensyaratkan suatu tingkat keuntungan yang lebih tinggi pada saham yang memberikan dividend yield tinggi dengan capital gains yield rendah daripada saham yang dividend yield rendah dengan capital gains yield tinggi.

4. Signalling theory. Miller dan Modigliani (1961) berpendapat bahwa suatu kenaikan dividen yang diatas biasanya merupakan suatu "sinyal" kepada para investor bahwa manajemen perusahaan meramalkan suatu penghasilan yang baik di masa mendatang. Sebaliknya, suatu penurunan dividen atau kenaikan dividen yang di bawah kenaikan normal biasanya diyakini investor sebagai suatu sinyal bahwa perusahaan menghadapi masa sulit di waktu mendatang.

5. Teori "Clientele Effect". Teori ini menyatakan bahwa kelompok (clientele) pemegang saham yang berbeda akan memiliki preferensi yang berbeda terhadap kebijakan dividen perusahaan. Kelompok pemegang saham yang membutuhkan penghasilan pada saat ini lebih menyukai suatu dividend payout ratio yang tinggi. Sebaliknya kelompok pemegang saham yang tidak begitu membutuhkan uang saat ini lebih senang jika perusahaan menahan sebagian besar laba bersih perusahaan.

6. Residual Theory of Dividends. Menurut teori dividen residual, perusahaan menetapkan kebijakan dividen setelah semua investasi yang menguntungkan habis dibiayai. Dengan kata lain, dividen yang dibayarkan merupakan sisa(residual) setelah semua usulan investasi yang menguntungkan habis dibiayai.

7. Teori Keagenan (Agency Theory). Paper mengenai penerapan teori keagenan diajukan oleh Michael C. Jensen dan William H. Mecking. Hubungan keagenan atau agency relationship muncul ketika satu atau lebih individu (majikan) menggaji individu lain (agen atau karyawan) untuk bertindak atas namanya, mendelegasikan kekuasaan untuk membuat keputusan kepada agen atau karyawannya. Dalam konteks manajemen, hubungan ini muncul antara: (1) pemegang saham (shareholders) dengan para manajer, serta (2) shareholders dengan kreditor (bondholders atau pemegang obligasi).

\section{Profitabilitas}

Rasio profitabilitas menurut Brigham dan Houston (2006:107) terjemahan Yulianto adalah sekelompok rasio yang menunjukkan gabungan efek-efek dari likuiditas, manajemen aktiva, dan utang pada hasil-hasil operasi. Raharjaputra (2009:205) menyatakan bahwa rasio profitabilitas adalah rasio yang mengukur kemampuan para eksekutif perusahaan dalam menciptakan tingkat keuntungan baik dalam bentuk laba perusahaan maupun nilai ekonomis atas penjualan, aset bersih perusahaan maupun modal sendiri, Rasio ini lebih diminati oleh para pemegang saham dan manajemen perusahaan sebagai salah satu alat keputusan investasi, apakah investasi bisnis ini akan dikembangkan, dipertahankan dan sebagainya. Sama halnya dengan Fahmi (2011:135) yang mendefinisikan bahwa rasio ini mengukur efektifitas manajemen secara keseluruhan yang ditujukan oleh besar kecilnya tingkat keuntungan yang diperoleh dalam hubungannya dengan penjualan maupun investasi. Rasio profitabilitas secara umum ada empat, yaitu gross profit margin, net profit margin, return on investment (ROI), dan return on equity (ROE).

Secara umum yang dipakai dalam pengukuran dari rasio profitabilitas atau rentabilitas adalah Return on Invesment (ROI) karena dapat mengukur kemampuan perusahaan secara keseluruhan di dalam menghasilkan keuntungan dengan jumlah keseluruhan aktiva yang tersedia di dalam perusahaan. Semakin tinggi tinggi rasio ini, semakin baik keadaan suatu perusahaan. 


\section{Set Kesempatan Investasi (Investment Investment Opportunity/IOS)}

Istilah IOS pertama kali diperkenalkan oleh Myers (1977) yang menguraikan perusahaan sebagai suatu kombinasi antara aktiva riil (assets in place) dan opsi investasi di masa depan. Menurut Hartono (2003:58), kesempatan Investasi atau Investment Opportunity Set (IOS) menggambarkan tentang luasnya kesempatan atau peluang investasi bagi suatu perusahaan. IOS merupakan nilai perusahaan yang besarnya tergantung pada pengeluaran-pengeluaran yang ditetapkan manajemen di masa yang akan datang. Bagi perusahaan yang tidak dapat menggunakan kesempatan investasi tersebut akan mengalami suatu pengeluaran yang lebih tinggi dibandingkan dengan nilai kesempatan yang hilang (Ahmad, 2009).

Set kesempatan investasi merupakan variabel yang tidak dapat diobservasi (variabel laten), sehingga diperlakukan proksi. Menurut Pagalung (2003) dalam Wardani dan Siregar (2009), proksi set kesempatan investasi dapat diklasifikasikan ke dalam empat tipe, yaitu:

a. Proksi Berdasarkan Harga (Price-Based Proxies)

Proksi ini didasarkan atas suatu ide bahwa prospek pertumbuhan perusahaan secara parsial dinyatakan dalam harga-harga saham, dan perusahaan yang tumbuh akan memiliki nilai pasar yang lebih tinggi secara relatif untuk aktiva-aktiva yang dimiliki.

b. Proksi Berdasarkan Investasi (Investment-Based Proxies)

Bentuk dari proksi ini adalah suatu rasio yang membandingkan suatu pengukuran investasi yang telah diinvestasikan dalam bentuk aktiva tetap atau suatu hasil operasi yang diproduksi dari aktiva yang telah diinvestasikan.

c. Proksi Berdasarkan Varian (Variance Measures)

Proksi set kesempatan investasi berdasarkan varian mengungkapkan bahwa suatu opsi akan menjadi lebih bernilai jika menggunakan variabilitas ukuran untuk memperkirakan besarnya opsi yang tumbuh, seperti variabilitas returnyang mendasari peningkatan aktiva.

d. Proksi Gabungan dari Proksi Individual

Alternatif proksi gabungan investasi dilakukan sebagai upaya untuk mengurangi measurement error yang ada pada proksi individual, sehingga akan menghasilkan pengukuran yang lebih baik untuk set kesempatan investasi.

\section{Likuiditas}

Likuiditas dapat diartikan sebagai kemampuan suatu perusahaan memenuhi kewajibankewajiban keuangannya dalam jangka pendek atau yang harus segera di bayar (Munawir 2002:93). Definisi yang lain adalah rasio yang digunakan untuk mengukur kemampuan perusahaan dalam memenuhi kewajiban jangka pendeknya yang telah jatuh tempo (Raharjaputra 2009:199). Rasio ini penting karena kegagalan dalam membayar kewajiban dapat menyebabkan kebangkrutan perusahaan. Secara umum rasio likudiitas ada dua, yaitu current ratio dan quick ratio (acid test ratio). Namun dalam penelitian ini, rasio likuiditas yang digunakan adalah current ratio. Menurut Fahmi (2011:121), current ratio adalah ukuran yang umum digunakan atas solvensi jangka pendek, kemampuan suatu perusahaan memenuhi kebutuhan utang ketika jatuh tempo.

\section{Kerangka Pemikiran}

\section{Pengaruh profitabilitas terhadap kebijakan dividen tunai}

Menurut Fahmi (2011:135), profitabilitas adalah rasio yang mengukur efektifitas manajemen secara keseluruhan yang ditujukan oleh besar kecilnya tingkat keuntungan yang diperoleh 
dalam hubungannya dengan penjualan maupun investasi. Rasio profitabilitas yang digunakan dalam penelitian ini adalah rasio return on investment (ROI), karena mengukur kemampuan perusahaan dalam menghasilkan keuntungan untuk menutup investasi yang dikeluarkan. Menurut Suharli (2007), profitabilitas mutlak diperlukan untuk perusahaan apabila hendak membayar dividen. Pihak manajemen akan membayarkan dividen untuk member sinyal mengenai keberhasilan perusahaan dalam membukukan profit. Sinyal tersebut menyimpulkan bahwa kemampuan perusahaan untuk membayar dividen merupakan fungsi dari keuntungan. Hal tersebut didukung oleh penelitian yang dilakukan oleh Arilaha (2009) yang memberikan hasil penelitian bahwa $R O I$ berpengaruh secara positif signifikan terhadap kebijakan dividen.

\section{Pengaruh set kesempatan investasi terhadap kebijakan dividen tunai}

Menurut Hartono (2003:58), set kesempatan Investasi (Investment Opportunity Set/IOS) menggambarkan tentang luasnya kesempatan atau peluang investasi bagi suatu perusahaan. IOS sebagai opsi investasi di masa depan dapat ditunjukkan dengan kemampuan perusahaan yang lebih tinggi di dalam mengambil kesempatan untuk mendapatkan keuntungan. Rasio yang digunakan untuk mengukur set kesempatan investasi dalam penelitian ini adalah rasio market to book value of assets (MBVA). Perusahaan yang memiliki level IOS tinggi mempunyai kebijakan pembayaran dividen yang lebih kecil dibandingkan dengan perusahaan yang memiliki level IOS rendah. Penentuan kebijakan pendanaan dan dividen dalam perusahaan berkaitan dengan masalah free cash flow perusahaan, di mana perusahaan yang pertumbuhannya rendah akan berusaha untuk menarik dana dari pihak luar untuk mendanai investasinya dengan mengorbankan sebagian besar labanya dalam bentuk dividen atau bunga. Oleh karena itu, perusahaan akan membayar dividen yang tinggi kepada para pemegang saham untuk menarik para investor (Inneke dan Supatmi, 2008). Hal tersebut didukung oleh penelitian yang dilakukan oleh Sadalia dan Saragih (2008), yang menemukan adanya hubungan yang negatif antara kesempatan investasi dengan kebijakan dividen.

\section{Pengaruh profitabilitas terhadap kebijakan dividen tunai dengan likuiditas sebagai variabel penguat}

Perusahaan yang memiliki likuiditas lebih baik maka akan mampu membayar dividen lebih banyak. Pada perusahaan yang membukukan keuntungan lebih tinggi (profitabilita tinggi), ditambah likuiditas yang lebih baik, maka semakin besar jumlah dividen yang dibagikan. Hal ini didukung oleh penelitian yang dilakukan oleh Suharli (2007) yang memberikan hasil bahwa profitabilitas berpengaruh secara positif signifikan terhadap kebijakan dividen tunai dan diperkuat oleh likuiditas perusahaan.

\section{Pengaruh set kesempatan investasi terhadap kebijakan dividen tunai dengan likuiditas sebagai variabel penguat}

Pada perusahaan yang menginvestasikan dana lebih banyak akan menyebabkan jumlah dividen tunai yang dibayarkan berkurang, namun likuiditas yang baik mampu memperlemah hipotesis tersebut, karena pada saat itu perusahaan dapat menunda pembayaran hutang jangka pendeknya. Likuiditas diartikan sebagai kemampuan perusahaan melunasi seluruh kewajiban jangka pendeknya dan mendanai operasional usahanya. Hanya perusahaan yang memiliki likuiditas yang baik akan membagikan labanya kepada pemegang saham dalam bentuk tunai. Sebaliknya, pihak manajemen perusahaan akan menggunakan potensi likuiditas yang ada untuk melunasi kewajiban jangka pendek ataupun mendanai operasi perusahaannya. Hal ini didukung oleh penelitian yang dilakukan oleh Suharli (2007) yang memberikan hasil 
bahwa set kesempatan investasi mempunyai pengaruh negatif terhadap kebijakan dividen tunai dengan likuiditas sebagai variabel penguat.

\section{Hipotesis Penelitian}

Berdasarkan teori dan kerangka pemikiran yang telah dijelaskan pada bagian sebelumnya, maka penelitian ini memiliki hipotesis sebagai berikut:

1. Profitabilitas berpengaruh positif signifikan terhadap kebijakan dividen tunai pada emiten Kompas 100.

2. Set kesempatan investasi berpengaruh negatif signifikan terhadap kebijakan dividen tunai pada emiten Kompas 100.

3. Profitabilitas berpengaruh positif signifikan terhadap kebijakan dividen tunai dengan likuiditas sebagai variabel penguat pada emiten Kompas 100.

4. Set kesempatan investasi berpengaruh negatif terhadap kebijakan dividen tunai dengan likuiditas sebagai variabel penguat pada emiten Kompas 100.

\section{METODE PENELITIAN}

Penelitian ini termasuk dalam penelitian deskriptif verifikatif bersifat kausalitas. Studi deskriptif menampilkan data dalam bentuk yang bermakna, membantu untuk: memahami karakteristik sebuah kelompok dalam situasi tertentu, memikirkan secara sistematis mengenai berbagai aspek dalam situasi tertentu, memberikan gagasan untuk penyelidikan dan penelitian lebih lanjut, dan/atau membuat keputusan tertentu yang sederhana (Sekaran, 2009:158). Penelitian verifikatif kausalitas karena penelitian ini disusun untuk meneliti kemungkinan adanya hubungan sebab akibat antar variabel (Sanusi, 2011:14).

\section{Variabel Operasional}

Menurut Sujarweni (2011:22) variabel adalah sesuatu yang berbentuk yang ditetapkan oleh peneliti dipelajari dengan seksama sehingga diperoleh informasi berupa data dan diolah dengan statistik sehingga dapat ditarik kesimpulan. Tabel 1 berikut ini menunjukkan variabel yang digunakan dalam penelitian ini.

Tabel 1.

\section{Operasionalisasi Variabel}

\begin{tabular}{|c|c|c|c|}
\hline $\begin{array}{l}\text { Variabel } \\
\text { Terukur }\end{array}$ & Konsep Variabel & Indikator & Skala \\
\hline $\begin{array}{l}\text { Profitabilitas } \\
\text { (X1) }\end{array}$ & $\begin{array}{l}\text { mengukur kemampuan para eksekutif } \\
\text { perusahaan dalam menciptakan tingkat } \\
\text { keuntungan baik dalam bentuk laba } \\
\text { perusahaan maupun nilai ekonomis } \\
\text { atas penjualan, aset bersih, dan modal } \\
\text { sendiri. (Raharjaputra, 2009:205). }\end{array}$ & Roi $\frac{\text { lababersih }}{\text { JumbatsetPerusaiaan }}$ & Rasio \\
\hline $\begin{array}{l}\text { Set Kesempatan } \\
\text { Investasi (X2) }\end{array}$ & $\begin{array}{l}\text { menggambarkan tentang luasnya } \\
\text { kesempatan atau peluang investasi bagi } \\
\text { suatu perusahaan (Hartono, 2003:58). }\end{array}$ & $\begin{array}{c}\text { MBVA } \\
\text { (total asset- total ekuitas }+(\text { lembar } \\
\text { saham beredar harga penutupan } \\
=\frac{\text { saham) }}{\text { Total asset }}\end{array}$ & Rasio \\
\hline
\end{tabular}




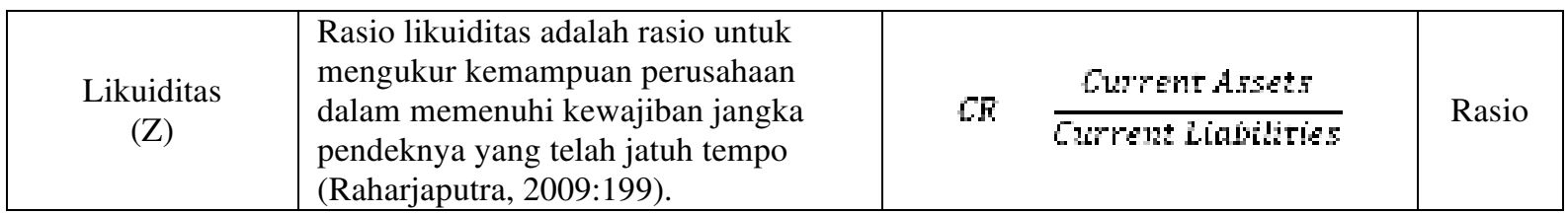

\section{Populasi dan sampel}

Populasi dalam penelitian ini adalah Indeks Kompas 100 yang berjumlah 100 perusahaan yang terdaftar di Bursa Efek Indonesia (BEI) periode 2008-2011. Pemilihan sampel dilakukan dengan metode purposive sampling. Table berikut menunjukkan pemilihan sampel yang akan digunakan dalam penelitian ini.

Tabel 2.

\section{Pemilihan sampel}

\begin{tabular}{|c|l|c|}
\hline 1. & Populasi : Perusahaan yang terdaftar dalam Kompas 100 di Bursa Efek Indonesia & 100 \\
\hline 2. & $\begin{array}{l}\text { Perusahaan yang tidak terdaftar secara konsisten dalam Kompas 100 di Bursa Efek Indonesia } \\
\text { selama periode pengamatan tahun 2008-2011 }\end{array}$ & $(45)$ \\
\hline 3. & $\begin{array}{l}\text { Perusahaan yang tidak mempublikasikan laporan keuangan tahunan yang telah diaudit dan } \\
\text { tidak membagikan dividen tunai dalam penelitian selama periode pengamatan dari tahun } \\
\text { 2008-2011 }\end{array}$ & $\begin{array}{l}(44) \\
\text { periode pengamatan dari tahun 2008-2011 }\end{array}$ \\
\hline 4. & $\begin{array}{l}\text { Perusahaan yang tidak mempublikasikan laporan keuangan dalam mata uang rupiah selama } \\
\text { Jumlah sampel yang dijadikan dalam objek penelitian }\end{array}$ \\
\hline
\end{tabular}

Penelitian ini menggunakan data sekunder. Data sekunder yang digunakan untuk menunjang dilaksanakannya penelitian adalah:Laporan keuangan Kompas 100 yang terdaftar di Bursa Efek Indonesia (BEI) pada tahun 2008-2011 yang telah diaudit, dan sumber yang berkaitan dengan penelitian yang dilaksanakan. Data yang digunakan adalah time series yaitu periode 2008-2011 yang diperoleh dari Indonesian Capital Market Directory (ICMD) dan JSX Statistics.

Metode pengumpulan data dalam penelitian ini menggunakan teknik pendidikan kepustakaan dan dokumentasi. Pendidikan kepustakaan adalah pengumpulan data dengan membaca dan mempelajari literatur seperti buku, jurnal, skripsi, dan sumber tertulis lainnya yang berkaitan dengan topik penelitian. Sementara dokumentasi adalah pengumpulan data mengenai hal-hal atau variabel yang berupa catatan, transkrip, buku, surat kabar, majalah dan sebagainya.

\section{Teknik Analisis Data}

\section{Moderated Regression Analysis (MRA)}

Analisis regresi merupakan hubungan antara dua variabel atau lebih. Bertujuan untuk meramalkan suatu nilai variabel dependen dengan adanya perubahan dari variabel independen (Priyatno, 2009:39). Dalam penelitian ini, analisis regresi yang digunakan adalah moderated regression analysis (MRA). Variabel moderating menurut Ghozali (2011:223) adalah variabel independen lainnya terhadap variabel dependen.Untuk melakukan penelitian dengan moderated regression analysis (MRA), maka dibuatlah persamaan sebagai berikut:

$$
Y=\alpha+\beta_{1} R O I+\beta_{2} M B V A+\beta_{3} C R+\beta_{4} R O I * C R+\beta_{5} M B V A * C R+\varepsilon
$$


Keterangan :

\begin{tabular}{|c|c|}
\hline Y & $=$ dividen payout ratio \\
\hline$\alpha$ & $=$ konstanta \\
\hline$\beta_{1}, \beta_{2}, \beta_{3}, \beta_{4}, \beta_{5}$ & $=$ koefisien regresi \\
\hline ROI & $=$ Return On Investment (profitabilitas) \\
\hline MBVA & $=$ set kesempatan investasi (Market Book Value to Asset) \\
\hline $\mathrm{CR}$ & $=$ Current Ratio $($ variabel moderator (likuiditas)) \\
\hline $\mathrm{ROI} * \mathrm{CR}$ & $=$ interaksi antara profitabilitas dan likuiditas \\
\hline $\mathrm{MBVA} * \mathrm{CR}$ & $=$ interaksi antara set kesempatan investasi dan likuiditas \\
\hline 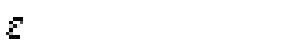 & $=$ variabel pengganggu \\
\hline
\end{tabular}

Menurut Ghozali (2011:235) kriteria Moderated Regression Analysis adalah apabila variabel interaksi memberikan tingkat signifikan $<0,05$.

Sebelum melakukan analisis regresi moderasi, perlu dilakukan uji asumsi klasik terlebih dahulu untuk menghindari terjadinya estimasi yang bias karena mengingat bahwa tidak semua data dapat diterapkan dengan menggunakan analisis regresi. Uji asumsi klasik terdiri dari uji normalitas, uji autokorelasi, uji multikolinearitas, dan uji heteroskedastisitas.

\section{Uji Signifikan Parameter Individual (Uji Statistik t)}

Uji statistik $\mathrm{t}$ pada dasarnya menunjukkan seberapa jauh pengaruh satu variabel penjelas/independen secara individual dalam menerangkan variasi variabel dependen.

Langkah-langkah yang dilakukan menurut Priyatno (2012:139) adalah sebagai berikut:

a) Pernyataan hipotesis nol dan alternatif

$\mathrm{H}_{\mathfrak{j} 1}$ : profitabilitas tidak berpengaruh positif signifikan terhadap kebijakan dividen tunai.

$\mathrm{Ha}_{1}$ : profitabilitas berpengaruh positif signifikan terhadap kebijakan dividen tunai.

$\mathrm{H}_{\mathfrak{d} 2}$ : set kesempatan investasi tidak berpengaruh signifikan terhadap kebijakan dividen tunai.

$\mathrm{Ha}_{2}$ : set kesempatan investasi berpengaruh negatif signifikan terhadap kebijakan dividen tunai.

$\mathrm{H}_{\mathbf{3} 3}$ : profitabilitas tidak berpengaruh negatif signifikan terhadap kebijakan dividen tunai dengan likuiditas sebagai variabel penguat.

$\mathrm{Ha}_{3}$ : profitabilitas berpengaruh negatif signifikan terhadap kebijakan dividen tunai dengan likuiditas sebagai variabel penguat.

$\mathrm{H}_{34}$ : set kesempatan investasi tidak berpengaruh negatif signifikan terhadap kebijakan dividen tunai dengan likuiditas sebagai variabel penguat.

$\mathrm{Ha}_{4}$ : set kesempatan investasi berpengaruh negatif signifikan terhadap kebijakan dividen tunai dengan likuiditas sebagai variabel penguat.

b) Memilih statistik uji, dengan menentukan tingkat signifikan $(\alpha)$ sebesar 0.05

Berdasarkan signifikansi dasar pengambilan keputusannya adalah jika signifikansi $>$ 0.05 , maka $\mathrm{H}_{\mathfrak{\jmath}}$ diterima, jika signifikansi $<0.05$, maka $\mathrm{H}_{\mathfrak{\jmath}}$ ditolak. 


\section{Koefisien Determinasi $\left(\mathbf{R}^{2}\right)$}

Koefisien determinasi $\mathrm{R}^{2}$ digunakan untuk mengetahui seberapa besar prosentase sumbangan pengaruh variabel independen secara serentak terhadap variabel dependen (Priyatno, 2009:56). $\mathrm{R}^{2}$ menjelaskan proporsi variasi dalam variabel terikat (Y) yang dijelaskan oleh variabel bebas (lebih dari satu variabel) secara bersama-sama. Persamaan regresi linear berganda semakin baik apabila nilai koefisien determinasi $\left(\mathrm{R}^{2}\right)$ semakin besar (mendekati 1$)$ dan cenderung meningkat nilainya sejalan dengan peningkatan jumlah variabel bebas (Sanusi, 2011:136).

\section{HASIL DAN PEMBAHASAN}

Variabel yang digunakan dalam penelitian ini adalah variabel independen terdiri dari profitabilitas dan set kesempatan invetasi, sedangkan variabel dependennya adalah kebijakan dividen tunai dan variabel moderasinya adalah likuiditas.

\section{Deskripsi Variabel Penelitian}

Penelitian ini menggunakan statistik deskriptif untuk mengetahui nilai minimum, nilai maksimum, mean (rata-rata), dan standar deviasi dari keseluruhan data penelitian. Hasil output SPSS adalah sebagai berikut:

Tabel 3.

Hasil Statistik Deskriptif

\begin{tabular}{|l|r|r|r|r|r|}
\hline & N & \multicolumn{1}{|c|}{ Minimum } & Maximum & Mean & \multicolumn{1}{c|}{ Std. Deviation } \\
\hline ROI & 40 & .03 & .40 & .1443 & .07785 \\
MBVA & 40 & .64 & 4.93 & 2.3193 & 1.23415 \\
DPR & 40 & .08 & 10.83 & .8864 & 1.95199 \\
CR & 40 & .54 & 6.99 & 2.2290 & 1.44071 \\
Valid N (listwise) & 40 & & & \\
\hline
\end{tabular}

Sumber: Output SPSS, Descriptive Statistics

Nilai minimum profitabilitas keseluruhan data yaitu 0,03 yang berarti bahwa kemampuan perusahaan secara keseluruhan di dalam menghasilkan keuntungan dengan jumlah keseluruhan aktiva yang tersedia di dalam perusahaan hanya 3\% saja. Nilai mean (rata-rata) keseluruhan data yaitu 0,1443, dapat diartikan bahwa kemampuan perusahaan secara keseluruhan di dalam menghasilkan keuntungan dengan jumlah keseluruhan aktiva yang tersedia di dalam perusahaan dengan rata-rata perusahaan kecil. Standar deviasi ROI yaitu 0,07785 yang menunjukkan bahwa data tidak bervariasi penyebarannya. Jika sebarannya bernilai 0 , maka nilai semua datanya adalah sama. Semakin besar nilai sebarannya berarti data semakin bervariasi

Nilai minimum set kesempatan investasi data keseluruhan adalah 0,64 yang berarti bahwa adanya pertumbuhan aktiva dan kesempatan investasi di masa yang akan datang $64 \%$. Nilai standar deviasi menunjukkan angka 1,23415 menunjukkan bahwa data bevariasi penyebarannya karena semakin besar data maka semakin bervariasi data tersebut. Rata-rata industri tahun 2011 sebesar 2,117 menunjukkan bahwa nilai pasar dihargai 2,117 kali dari nilai buku aktivanya. 
Nilai minimum Dividend Payout Ratio (DPR) dari seluruh data yaitu 0,08 yang berarti bahwa besarnya pembayaran dividen oleh perusahaan sebesar Rp 0,08. Nilai maksimum dari data keseluruhan yaitu 10,83. Nilai rata-rata perusahaan dari data keseluruhan berjumlah 0,8864. Rata-rata industri tahun 2011 sebesar 0,677 menunjukkan bahwa persentase dari pendapatan yang akan dibayarkan kepada para pemegang saham sebagai dividen kas sebesar $67,7 \%$.

Nilai minimum Current Ratio $(C R)$ dari seluruh data yaitu 0,54 yang berarti bahwa setiap Rp 1 hutang lancar perusahaan dapat dijamin oleh aset lancar Rp 0,54. Nilai maksimum dari data keseluruhan yaitu 6,99. Nilai rata-rata perusahaan dari data keseluruhan berjumlah 2,2290. Rata-rata industri tahun 2011 sebesar 2,801. Hal ini berarti bahwa setiap Rp 1,00 kewajiban lancar peerusahaan dijamin pembayarannya oleh $\mathrm{Rp} 2,801$ aset lancar. Semakin tinggi jumlah kelipatan asset lancar terhadap kewajiban lancar, maka semakin besar keyakinan bahwa kewajiban lancar tersebut akan di bayar.

Untuk meneliti pengaruh profitabilitas dan set kesempatan investasi terhadap kebijakan dividen tunai dengan likuiditas sebagai variabel penguat, maka penulis menggunakan moderated regression analysis sebagai alat analisis data yang sebelumnya harus lolos uji asumsi klasik. Uji Asumsi Klasik tersebut adalah:

\section{Uji Normalitas}

Uji Kolmogorov Smirnov menunjukkan bahwa seluruh variabel sama berdistribusi normal, karena tingkat signifikan yang diperoleh lebih besar dari nilai signifikan yang ditetapkan yaitu 0,05. Hasil perhitungan profitabilitas sebesar $0,840>0,05$, set kesempatan investasi sebesar 0,555 >0,05, kebijakan dividen sebesar 0,268 >0,05 yang berarti data residual berdistribusi secara normal. Begitu juga hasil perhitungan moderat menunjukkan bahwa tingkat signifikan yang diperoleh lebih besar dari nilai signifikan yang ditetapkan yaitu 0,05 . Sehingga dapat disimpulkan bahwa data dalam penelitian ini adalah berdistribusi normal.

2. Uji Autokorelasi

Dalam penelitian ini uji autokorelasi yang digunakan adalah uji Statistik $Q$ : Box-Pierce dan Ljung Box. Dari hasil pengujian tidak terdapat nilai yang signifikan, sehingga dapat disimpulkan tidak terjadi autokorelasi.

3. Uji Multikolinearitas

Dari hasil uji, terlihat bahwa seluruh variabel memiiliki nilai VIF dibawah 10, hal tersebut menandakan bahwa tidak terjadi multikolinearitas atau tidak ada korelasi antar variabel.

4. Uji Heteroskedastisitas

Salah satu cara untuk menguji adanya heteroskedastisitas dapat dilakukan dengan melihat ada tidaknya pola tertentu pada grafik Scatterplot antara variabel dependen dengan residualnya. Apabila pada pola Scatterplot ditunjukkan dengan titik-titik membentuk suatu pola tertentu maka telah terjadi heteroskedastisitas. Sebaliknya apabila titik-titik grafik tidak membentuk pola tertentu maka tidak terjadi heteroskedastisitas. Berikut grafik Scatterplot hasil uji heteroskedastisitas. Dari grafik scatterplot terlihat bahwa titik-titik menyebar secara acak serta tersebar diatas maupun dibawah angka 0 pada sumbu Y. Sehingga dapat disimpulkan bahwa tidak terjadi heteroskedastisitas pada model regresi dan model regresi layak untuk memprediksi variabel. 


\section{Pengujian Hipotesis}

\section{Koefisien Determinasi Moderated Regression Analysis}

Koefisien determinasi $\mathrm{R}^{2}$ digunakan untuk mengukur seberapa jauh kemampuan model dalam menerangkan variasi variabel dependen. Nilai $\mathrm{R}^{2}$ dapat dilihat melalui tabel model summary hasil output SPSS. Berikut adalah tabel hasil uji koefisien determinasi $\mathrm{R}^{2}$ :

Tabel 4.

Hasil Uji Koefisien Determinasi MRA

\begin{tabular}{|l|r|r|r|rr|}
\hline Model & \multicolumn{1}{|c|}{$\mathrm{R}$} & R Square & \multicolumn{1}{|c|}{ Adjusted R Square } & \multicolumn{2}{|c|}{ Std. Error of the Estimate } \\
\hline 1 & $.506^{\mathrm{a}}$ & .256 & .147 & .98892 \\
\hline
\end{tabular}

Sumber: Output SPSS, Model Summary

Dari tabel 4 dapat diketahui bahwa nilai koefisien determinasi $\mathrm{R}^{2}$ adalah 0,256 atau 25,6\% dengan tingkat signifikansi 0, lebih besar dari 0,05. Dapat dikatakan 25,6\% profitabilitas dan set kesempatan investasi terhadap kebijakan dividen tunai tidak dipengaruhi oleh interaksi likuiditas. Sisanya $74,4 \%$ dijelaskan oleh variabel independen lainnya yang tidak diteliti oleh penulis.

\section{Uji t Moderated Regression Analysis}

Dalam penelitian ini, analisis regresi yang digunakan adalah moderated regression analysis (MRA). Variabel moderating menurut Ghozali (2011:223) adalah variabel independen lainnya terhadap variabel dependen. Hasil uji statistik t Moderated Regression Analysis adalah sebagai berikut:

Tabel 5. Uji t Moderated Regression Analysis Coefficients ${ }^{\mathrm{a}}$

\begin{tabular}{|c|c|c|c|c|c|c|}
\hline & \multirow[b]{2}{*}{ Model } & \multicolumn{2}{|c|}{ Unstandardized Coefficients } & \multirow{2}{*}{$\frac{\text { Standardized Coefficients }}{\text { Beta }}$} & \multirow[b]{2}{*}{$\mathrm{t}$} & \multirow[b]{2}{*}{ Sig. } \\
\hline & & $\mathrm{B}$ & Std. Error & & & \\
\hline \multirow[t]{6}{*}{1} & (Constant) & -3.865 & 1.927 & & -2.006 & .053 \\
\hline & ROI & 6.141 & 5.126 & .445 & 1.198 & .239 \\
\hline & MBVA & -.952 & .365 & -1.097 & -2.605 & .014 \\
\hline & $\mathrm{CR}$ & -.282 & .310 & -.379 & -.909 & .369 \\
\hline & LnROI_CR & -1.220 & .573 & -1.199 & -2.129 & .041 \\
\hline & LN_MBVA_CR & 2.298 & .746 & 2.069 & 3.082 & .004 \\
\hline
\end{tabular}

a. Dependent Variable: LNDPR

Sumber: Output SPSS, Model Summary

Analisis regresi ini untuk menguji variabel independen yaitu profitabilitas dan set kesempatan investasi dalam mempengaruhi kebijakan dividen tunai dengan likuiditas sebagai variabel penguat. Secara sistematik persamaan tersebut dapat dirumuskan sebagai berikut:

$D P R=-3,865+6,141$ ROI - 0,952 MBVA - 0.282 CR - 1,220 ROI*CR + 2,298 MBVA*CR + E 
Persamaan diatas dapat diuraikan sebagai berikut:

1.

$\beta_{1}=6.141$ artinya jika ROI

meningkat sebesar 1 satuan dan variabel lainnya konstan, maka kebijakan dividen tunai akan meningkat sebesar 6,141 satuan.

2. $\beta_{2}=-0,952$ artinya jika MBVA (market to book value of assets) meningkat sebesar 1 satuan dan variabel lainnya konstan, maka kebijakan dividen tunai akan menurun sebesar 0,952 satuan.

3. $\dot{\beta}_{4}=-1,220$ artinya jika ROI (return on investment) meningkat sebesar 1 satuan dan didukung dengan likuiditas serta variabel lainnya konstan, maka kebijakan dividen tunai akan menurun sebesar 1,220 satuan

4. $\mathrm{B}_{5}=2,298$ artinya jika MBVA (market to book value of assets) meningkat sebesar 1 satuan dan didukung dengan likuiditas serta variabel lainnya konstan, maka kebijakan dividen tunai akan meningkat sebesar 2,298 satuan

\section{Pembahasan Penelitian}

\section{Pengaruh Profitabilitas terhadap Kebijakan Dividen Tunai.}

Profitabilitas yang diukur dengan ROI tidak berpengaruh signifikan dengan arah positif terhadap kebijakan dividen tunai. Hal tersebut dapat dilihat dari tingkat signifikan sebesar 0,239 (lihat table 5) yang lebih besar dari 0,05 yang berarti bahwa $\mathrm{Ho}_{1}$ diterima. Hal tersebut sesuai dengan penelitian Fahrurrozi (2007) yaitu ROI tidak berpengaruh terhadap kebijakan dividen tunai dengan arah positif.

Penelitian ini menunjukkan bahwa tinggi rendahnya profitabilitas yang dihasilkan perusahaan tidak dapat mempengaruhi pembayaran dividen tunai karena laba yang dihasilkan perusahaan dapat berupa laba non kas. Dimana komponen laba itu terdiri dari penjualan dan beban. Penjualan yang dilakukan perusahaan dapat berasal dari penjualan tunai maupun kredit. Apabila penjualan kredit perusahaan besar maka laba yang dihasilkan berupa laba non kas. Hal tersebut tidak dapat mempengaruhi pembayaran dividen tunai karena dividen tunai dibayarkan dalam bentuk kas bukan non kas.

\section{Pengaruh Set Kesempatan Investasi terhadap Kebijakan Dividen Tunai.}

Set kesempatan investasi yang diukur dengan MBVA (market to book value of assets) berpengaruh signifikan terhadap kebijakan dividen tunai dengan arah negative. Hal tersebut dapat dilihat dari tingkat signifikan sebesar 0,014 lebih besar dari 0,05 yang berarti bahwa $\mathrm{Ha}_{2}$ diterima (lihat tabel 5). Hal tersebut sesuai dengan penelitian Amah (2012) dan Inneke (2008) bahwa set kesempatan investasi berpengaruh signifikan terhadap kebijakan dividen tunai dengan arah negatif.

Perusahaan yang memiliki level Investment Opportunity Set (IOS) tinggi mempunyai kebijakan pembayaran dividen yang lebih kecil dibandingkan dengan perusahaan yang memiliki level IOS rendah. Hal ini dikarenakan perusahaan dengan set kesempatan investasi yang tinggi yang ditandai dengan pertumbuhan yang tinggi, membutuhkan dana yang besar untuk memenuhi kebutuhan investasinya. Jika perusahaan memutuskan untuk menggunakan sumber dana internal maka jumlah dividen yang dibayarkan akan cenderung menurun. Hal ini sesuai dengan teori dividen residual bahwa perusahaan menetapkan kebijakan dividen setelah 
semua investasi yang menguntungkan habis dibiayai. Dengan kata lain, dividen yang dibayarkan merupakan nilai sisa (residual) setelah semua usulan investasi yang menguntungkan habis dibiayai.

\section{Pengaruh Profitabilitas terhadap Kebijakan Dividen Tunai dengan Likuiditas sebagai Variabel Penguat.}

Profitabilitas yang diukur dengan $R O I$ berpengaruh signifikan terhadap kebijakan dividen tunai dengan likuiditas sebagai variabel moderate karena nilai signifikan sebesar 0,041 lebih kecil dari 0,05 dengan arah negatif. Arah negatif ditunjukkan dengan nilai koefisien regresi sebesar -1,220 (lihat tabel 5). Hal ini menunjukkan bahwa likuiditas mampu memoderasi hubungan profitabilitas terhadap kebijakan dividen. Hal ini sesuai dengan penelitian Nurjannah (2011) yang menyatakan bahwa likuiditas mampu memoderasi hubungan ROI terhadap kebijakan dividen tunai dengan arah negatif. Namun hasil ini bertentangan dengan penelitian Suharli (2007) yang menyatakan bahwa profitabilitas berpengaruh secara positif signifikan terhadap kebijakan dividend an diperkuat oleh likuiditas perusahaan.

Perusahaan yang memiliki profitabilitas tinggi didukung dengan likuiditas yang tinggi dapat memperkecil pembayaran dividen. Hal ini dikarenakan laba perusahaan dialokasikan oleh manajemen untuk disimpan sebagai laba ditahan untuk investasi masa depan dan likuiditas perusahaan merupakan salah satu pertimbangan utama dalam kebijakan dividen. Menurut Van Horne (2007 : 282) dividen merupakan arus kas keluar, maka semakin besar jumlah kas yang tersedia dan likuiditas perusahaan, semakin besar pula kemampuan perusahaan untuk membayar dividen. Dalam kondisi seperti ini mungkin saja perusahaan tidak likuid karena dananya digunakan untuk aktiva tetap dan modal kerja permanen untuk investasi masa depan. Oleh karena itu, kemungkinan perusahaan enggan membayar dividen dalam jumlah besar apabila manajemen perusahaan ingin memelihara likuiditas dalam mengantisipasi adanya ketidakpastian dan agar mempunyai fleksibilitas keuangan.

\section{Pengaruh IOS terhadap Kebijakan Dividen Tunai dengan Likuiditas sebagai Variabel Penguat.}

Set kesempatan investasi yang diukur dengan $M B V A$ berpengaruh signifikan terhadap kebijakan dividen tunai dengan likuiditas sebagai variabel penguat karena nilai signifikan 0,04 lebih kecil dari 0,05 dengan arah positif (lihat table 5). Arah positif ditunjukkan dengan nilai koefisien regresi sebesar 2,298. Hal ini menunjukkan bahwa likuiditas mampu memoderasi hubungan set kesempatan investasi terhadap kebijakan dividen. Hal tersebut sesuai dengan penelitian Suharli (2007) bahwa likuiditas mampu memoderasi hubungan set kesempatan investasi terhadap kebijakan dividen tunai dengan arah positif.

Semakin tingginya set kesempatan investasi didukung dengan likuiditas yang baik, maka dapat meingkatkan pembayaran dividen tunai. Perusahaan yang menggunakan laba yang tersedia untuk laba ditahan guna investasi di masa yang akan datang dan didukung dengan likuiditas yang baik, maka dapat meningkatkan kepercayaan investor karena menunjukkan bahwa tingginya set kesempatan investasi yang dilakukan perusahaan kelak dapat menghasilkan keuntungan yang dapat memberikan hasil kepada perusahaan. Sehingga perusahaan dapat meningkatkan pembayaran dividen tunainya kepada para pemegang saham. Perusahaan dalam melakukan investasi untuk memberi kesan kepada pemegang saham bahwa perusahaan mempunyai prospek yang baik di masa yang akan datang. 


\section{SIMPULAN}

Berdasarkan analisis yang telah dilakukan melalui regresi linear berganda dan moderated regression analysis, maka dapat dibuat kesimpulan sebagai berikut:

1. Profitabilitas yang diukur dengan ROI (return on investment) tidak berpengaruh signifikan dengan arah positif terhadap kebijakan dividen tunai.

2. Set kesempatan investasi (IOS) berpengaruh signifikan dengan arah negative terhadap kebijakan dividen tunai.

3. Profitabilitas berpengaruh signifikan terhadap kebijakan dividen tunai dengan likuiditas sebagai variable penguat dengan arah negatif. Likuiditas mampu memoderasi hubungan profitabilitas terhadap kebijakan dividen tunai.

4. Set kesempatan investasi berpengaruh signifikan terhadap kebijakan dividen tunai dengan likuiditas sebagai variable penguat dengan arah positif. Likuiditas mampu memoderasi hubungan set kesempatan investasi terhadap kebijakan dividen tunai.

Berdasarkan simpulan tersebut maka dapat dibuat saran sebagai berikut:

1. Penelitian selanjutnya dapat menambah atau mengganti variabel yang diteliti dengan variabel lainnya.Karena penelitian ini menunjukkan bahwa nilai $\mathrm{R}^{2}$ kecil sebesar 25,6\%. Berarti bahwa terdapat $74,4 \%$ variabel lain yang tidak diteliti oleh peneliti dapat menjelaskan variabel kebijakandividentunai. Jadi masih ada variabel lain seperti free cash flow, kepemilikan manajerial, ukuran perusahaan, dan kebijakan hutang yang dapat mempengaruhi kebijakan dividen tunai.

2. Penelitian selanjutnya dapat menggunakan objek penelitian yang berbeda dengan penelitian ini agar dapat menganalisis kebijakan dividen tunai seperti pada indeks LQ45 dan Jakarta Islamic Indeks.

3. Bagi emiten indeks Kompas 100 yang terdaftar di BEI, Perusahaan sebaiknya tidak hanya memperhatikan keuntungan perusahaan saja tanpa memperhatikan kemakmuran pemegang saham dengan tidak membagikan dividen tunai. Perusahaan seharusnya dapat menerapkan kebijakan dividen yang optimal dimana kebijakan tersebut dapat menciptakan keseimbangan di antara dividen saat ini dan pertumbuhan di masa yang akan datang. Selain itu perusahaan juga perlu memperhatikan investasi yang menguntungkan di masa yang akan datang karena investasi yang menguntungkan menghasilkan profit bagi perusahaan. Perusahaan yang memiliki likuiditas yang baik menunjukkan bahwa perusahaan itu sehat dari sisi keuangan karena ia mampu membayar semua biaya yang harus dikeluarkan dalam jangka pendeknya dan mendanai operasionalnya. Selain itu, likuiditas yang baik mampumeningkatkan kepercayaan para invetorterhadap perusahaan sehingga mengurangi ketidakpastian investor dalam menanamkan dananya ke dalam perusahaan.

4. Bagi Investor sebaiknya perlu memperhatikan faktor-faktor yang mempengaruhi kebijakan dividen tunai seperti, set kesempatan investasi, dan likuiditas perusahaan. Investor perlu memperhatikan investasi-investasi yang akan dilakukan oleh suatu perusahaan. Apabila perusahaan tersebut melakukan investasi di masa yang akan datang kemungkinan perusahaan tidak dapat membayar dividen tunainya. Dalam kondisi seperti ini investor dapat melihat posisi likuiditas perusahaan. Apabila likuiditas perusahaan baik, berarti perusahaan dapat mendanai operasional dan kewajiban jangka pendeknya. Sehingga ini dapat dijadikan dalam pengambilan keputusan dalam berinvestasi. 


\section{DAFTAR REFERENSI}

Adminkepri. (2011). Adaro bagikan deviden Rp970 miliar. [online]. http://wwwbisniskepri.com. [24 Februari 2013].

Ahmad, Rizal. (2009). Pengaruh profitabilitas dan Investment Opportunity Set Terhadap kebijakan Dividen Tunai. Jurnal Ilmiah Abdi Ilmu ISSN, Vol 2. No.2, 175-188.

Amah, Nik. (2012). Faktor-faktor Yang Mempengaruhi Dividend Policy Perusahaan Go Public Di Indonesia. Jurnal Akuntansi dan Pendidikan, Vol 1. No.1, 45-55.

Arifin, Zaenal. (2005). Teori Keuangan dan Pasar Modal. Yogyakarta: Ekonisia.

Arilaha, Muhammad Asril. (2009). Pengaruh Free Cash Flow, Profitabilitas, Likuiditas, dan Leverage Terhadap Kebijakan Dividen. Jurnal Keuangan dan Perbankan, Vol 13. No. 1, 7887.

Atmaja, Lukas Setia. (2008). Teori dan Praktek Manajemen Keuanga Edisi Pertama. Yogyakarta: Andi Offset.

Bringham, Eugene F and Joel F.Houston. (2006). Dasar-Dasar Manajemen Keuangan, alih bahasa Ali Akbar Yulianto, Buku Satu, Edisi Sepuluh. Jakarta: Salemba Empat.

Darminto. (2008). Pengaruh Profitabilitas, Likuiditas, Struktur Modal, dan Struktur Kepemilikan Saham terhadap Kebijakan Dividen. Jurnal Ilmu Sosial, Vol 20. No.2, 87-97.

Fahmi, Irham. (2011). Analisis Laporan Keuangan Panduan Bagi Akademis, Manajer, dan Investor untuk Menilai dan Menganalisis Bisnis dari Aspek Keuangan. Bandung: Alfabeta.

Fahrurrozy. (2007). Analisis Faktor Faktor Yang Mempengaruhi Penentuan Kebijakan Pembagian Dividen Pada Perusahaan Manufaktur Di Bursa Efek Indonesia. Jurnal Tepak Manajerial Magister Manajemen UNRI, Vol 7. No. 7, 29- 42.

Ghozali, Imam. (2011). Aplikasi Analisis Multivariate dengan Program IBM SPSS 19. Semarang: Badan Penerbit Universitas Diponegoro.

Inneke, Theoral Maria dan Supatmi. (2008). Analisis Investment Opportunity Set (IOS) Dan Profitabilitas Dalam Memoderasi Pengaruh Kebijakan Dividen Terhadap Tingkat Leverage Perusahaan. Jurnal Akuntansi. No.03, 277-288.

Marpaung, dan Hadianto. (2009). Pengaruh Profitabilitas dan Kesempatan Investasi terhadap Kebijakan Dividen: Studi Empirik pada Emiten Pembentuk Indeks LQ45 di Bursa Efek Indonesia. Jurnal Akuntansi, Vol 1. No. 1, 70-84.

Munawir S. (2002). Analisis Informasi Keuangan. Yogyakarta: Liberty.

Priyatno, Duwi. (2009). SPSS untuk Analisis Korelasi, Regresi, dan Multivariate. Yogyakarta: Gava Media. 
Raharjaputra, Hendra S. (2009). Manajemen Keuangan dan Akuntansi untuk Eksekutif Perusahaan. Jakarta: Salemba Empat.

Sadalia, Isfenti dan Saragih, Nurul Sari Syafitri. (2008). Pengaruh Profitability dan Investment Opportunity Set Terhadap Dividen Tunai Pada Perusahaan Terbuka Di Bursa Efek Indonesia. Jurnal Manajemen Bisnis, Vol 1. No. 3, 103-108.

Sanusi, Anwar. (2011). Metodologi Penelitian Bisnis. Jakarta: Salemba Empat.

Sekaran, Uma. (2009). Metedologi Penelitian untuk Bisnis. Jakarta: Salemba Empat.

Stice, Earl K., James D. Stice, fred Skousen. (2005). Intermediate Accounting, Alih Bahasa Barlev Nicodemus, Akuntansi Keuangan Menengah, Jilid 1. Jakarta: Salemba Empat.

Sugiyono. (2007). Metodologi Penelitian Kuantitatif, Kualitatif, dan Kombinasi (Mixed Methods). Bandung: Alfabeta.

Suharli, Michell dan Oktarina. (2005). Memprediksi Tingkat Pengembalian Investasi Pada Equity Securities Melalui Rasio Profitabilitas, Likuiditas, dan Hutang Pada Perusahaan Publik Di Jakarta. Kumpulan Makalah Simposium Nasional Akuntansi 8. Solo.

Suharli, Michell. (2007). Pengaruh Profitability dan Investment Opportunity Ser terhadap Kebijakan Dividen Tunai dengan Likuiditas sebagai Variabel Penguat. Jurnal Akuntansi dan Keuangan, Vol 9. No. 1, 9-17.

Sujarweni, V.Wiratna dan Poly Endrayanto. (2011). Statistika Untuk Penelitian. Yogyakarta: Graha Ilmu.

Suryanto. (2012). Apple Setuju Ubah Susunan Direksi. [online]. http://m.antaranews.com. [23 Februari 2013].

Van Horne, James C. (2007). Prinsip-Prinsip Manajemen Keuangan, Buku 2 Edisi 12. Jakarta:Salemba Empat.

Warsono. (2003). Manajemen Keuangan Perusahaan, Jilid Satu. Malang: Bayumedia.

Wirjolukito, A. Yanto, H dan Sandy. (2003). Faktor-Faktor Yang Merupakan Pertimbangan Dalam Keputusan Pembagian Dividen : Tinjauan Terhadap Teori Persinyalan Dividen Pada Perusahaan Go Public Di Indonesia. Jurnal Ekonomi dan Bisnis, Vol 6. No. 1, 78-89 